\title{
POPULATION DYNAMICS OF Hypothenemus hampei (COLEOPTERA: SCOLYTIDAE) IN AGROFORESTRY AND MONOCULTURE SYSTEMS OF CONILON COFFEE IN THE SOUTHERN PORTION OF THE STATE OF AMAZONAS, BRAZIL
}

\author{
Juliana Formiga Botelho ${ }^{2 *} \odot$, Ruan Sobreira de Queiroz ${ }^{3} \odot$, Marcelo Rodrigues dos Anjos ${ }^{4} \odot$ and \\ Moisés Santos de Souza ${ }^{4}$ (C)
}

\begin{abstract}
${ }^{1}$ Received on 10.12.2020 accepted for publication on 14.05.2021.
${ }^{2}$ Universidade Federal do Amazonas,Graduanda em Agronomia, Humaitá, AM - Brasil. E-mail: <julianabottelho10@gmail.com>.

${ }^{3}$ Universidade Federal do Amazonas,Graduando em Agronomia, Humaitá, AM - Brasil. E-mail: < ruanqueiroz98@gmail.com>.

${ }^{4}$ Universidade Federal do Amazonas,Instituto de Educação Agriculura e Ambiente, Humaitá, AM - Brasil. E-mail: <anjos@ufam .edu.br > and $<$ moisesantos@ufam.edu.br>.

*Corresponding author.
\end{abstract}

\begin{abstract}
Hypothenemus hampei is the main coffee pest in the Amazon and worldwide. Although coffee cultivation exists in the State of Amazonas, there is no information regarding the behavior of this species population in this region of Brazil. Since the Amazon region is a favorable environment for H. hampei, the present study aimed to investigate this insect population in the following cultivation systems implanted in the municipality of Humaitá, Southern Amazonas: $i$ ) coffee in native forest (CNF), ii) coffee intercropped with cupuaçu and açaí (native Brazilian fruits) (CCA) and iii) coffee in monoculture (MC). Also, the climatic and phenological parameters of the plant were used in relation with the population dynamics of the insect. For that, ten baited traps were installed in each field for the monthly sampling of the H. hampei population from July/2018 to June/2019. The highest population abundance of the insect was observed during the coffee flowering season, mainly in monoculture crops, when compared to the other intercropped fields. The total mean value of the insect population observed in the three environments evaluated was highest in August/2018, with a recorded value of 1749 . The increase in rainfall indexes occurred simultaneously with a decrease in the insect population; this coincides with the end of the flowering season (October/2018, $161.8 \mathrm{~mm}$ ) and the beginning of grain formation (November/2018, $234.8 \mathrm{~mm}$ ). The lowest abundance of the insect observed in the coffee fields in native forest, with an abundance of $83(\mathrm{CNF})$, indicates that the local biodiversity disfavors the population size of the pest in the environment. These results suggest that phenological phases of conilon coffee and the influence of climatic conditions can result in changes in the population dynamics of the H. hampei. Coffee agroforestry systems are more promising to maintain this population at low levels.
\end{abstract}

Keywords: Coffee berry borer; Bioecology; Baited traps.

\section{DINAMICA POPULACIONAL DE Hypothenemus hampei (COLEOPTERA: SCOLYTIDAE) SOB SISTEMA AGROFLORESTAL E MONOCULTIVO DE CAFÉ CONILON NO SUL DO ESTADO DO AMAZONAS, BRASIL.}

\begin{abstract}
RESUMO - A broca-do-café, Hypothenemus hampei, é a principal praga do cafeeiro na Amazônia e em todo mundo. Embora haja cultivo de café no estado do Amazonas, não há informações sobre o comportamento da população desta espécie nesta região do Brasil. Como a região amazônica é um ambiente propício para o H. hampei, o presente trabalho objetivou investigar a população do inseto em diferentes sistemas de cultivo implantadas no municipio de Humaitá, Sul do Amazonas: i) café em floresta nativa (CFN), ii) café consorciada com cupuaçu e açaí (CCA) e iii) café em monocultivo (MC). Também, utilizou-se os parâmetros climáticos e fenológico da planta para relacionar com a dinâmica populacional do inseto. Para isso, instalaram-se 10 armadilhas iscadas em cada lavoura para amostragens mensais da população do $\boldsymbol{H}$. hampei durante Julho/2018 a Junho/2019. A maior abundância populacional do inseto foi observada durante a floração do café, principalmente na lavoura de monocultivo, em relação às demais lavouras consorciadas. O valor médio total da
\end{abstract}

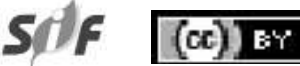

Revista Árvore 2021;45:e4524 http://dx.doi.org/10.1590/1806-908820210000024 


\begin{abstract}
população do inseto observada nos três ambientes investigados é maior no mês de agosto/2018, registrandose o valor de 1749. O aumento dos índices pluviométricos ocorreu simultaneamente com a diminuição da população inseto, isso coincide com o final da floração (outubro/2018, $161.8 \mathrm{~mm}$ ) e início da granação dos frutos (novembro/2018, $234.8 \mathrm{~mm}$ ). A menor abundância do inseto observada na lavoura sob floresta nativa, abundância de 83 (CFN), indica que a biodiversidade local desfavorece o tamanho populacional da praga no ambiente. As fases fenológicas do café conilon e a influência das condições climáticas podem resultar em mudanças na dinâmica populacional de H. hampei. Os cafeeiros em sistemas agroflorestais são mais promissores para manter essa população em níveis baixos.
\end{abstract}

Palavras-Chave: Broca-do-café; Bioecologia; Armadilhas iscadas.

\section{INTRODUCTION}

Coffee was introduced into Brazil starting with the Amazon region, where the first seeds were planted in the State of Pará, originating from French Guiana (Homma, 2003). Currently, the largest coffee producer in the Amazon region is the state of Rondonia, standing out as one of the country's main 'Conilon' coffee producers (Coffea canephora) (Marcolan and Espindula, 2015). Besides that, in some areas in southeastern Amazonas, planting coffee in an agroforestry system, as occurs in the municipality of Apuí, is already underway (Figueiredo et al., 2016).

Hypothenemus hampei (Coleoptera: Scolytidae) remains one of the main problems hindering coffee production, especially in regions with low technological standards, like the Brazilian Amazon. In addition to the technical aspects, environmental conditions that favor the susceptibility of coffee to H. hampei attacks are prevalent (Marcolan and Espindula, 2015). These factors favor the progress of pest infestation, consequently increasing the percentage of infested grains, resulting in an inferior product, with a reduction in quality and commercial value (Souza et al., 2018).

Environmental conditions can influence the population density of this pest (Price, 1997). For example, borer infestations can be influenced by several factors such as climate, harvest, shading, spacing and altitude (Souza and Reis, 1997). Coincidentally, in the context of integrated pest management, knowing the distribution, abundance and behavior of this insect can be an important tool for designing insect pest control (Yadav and Chang, 2014).

Other studies demonstrate that an insect's behavior is dependent on and determined by plant phenological stages (Posledovich et al., 2018; Gherlenda et al., 2016; Kapkoti et al., 2016; Nielsen et al., 2011; Masante-Roca et al., 2007). Likewise, the phenology of coffee plants has implications for the H. hampei population, and some studies indicate that maximum reproduction and abundance of this species occur in specific stages of coffee's phenological cycle (Fernandes et al., 2015; Mathieu et al., 1997).

There are no previous reports describing the population dynamics of $H$. hampei in the state of Amazonas. Highly compromising levels are reported in other states in the Amazon region, like Rondônia (Souza et al., 2020; Souza et al., 2018; Souza et al., 2014; Costa et al., 2002). Thus, in order to better elucidate the population of this pest in the state of Amazonas, the objective of this study was to evaluate and report the population dynamics of $H$. hampei using climatic parameters, plant phenology and different coffee planting systems in the Amazonian environment.

Crops in the region surrounding the municipality of Humaitá, Amazonas are found on family farms, without the application of agricultural inputs and adequate management practices. Therefore, the data revealed from this research study are important for generating information that helps in establishing appropriate criteria for integrated pest management, allowing for increased coffee productivity, according to the peculiarities of the Amazon region.

Thereby, in this study, the population dynamics of $H$. hampei in the Amazon environment were evaluated considering the phenological cycle of coffee (flowering, grain formation, maturation and rest) and climatic variables (temperature, relative humidity and precipitation).

\section{MATERIAL AND METHODS}

\subsection{Study location and description}

Monitoring was carried out on three 'Conilon' coffee properties (C. canephora) in the municipality

Revista Árvore 2021;45:e4524 


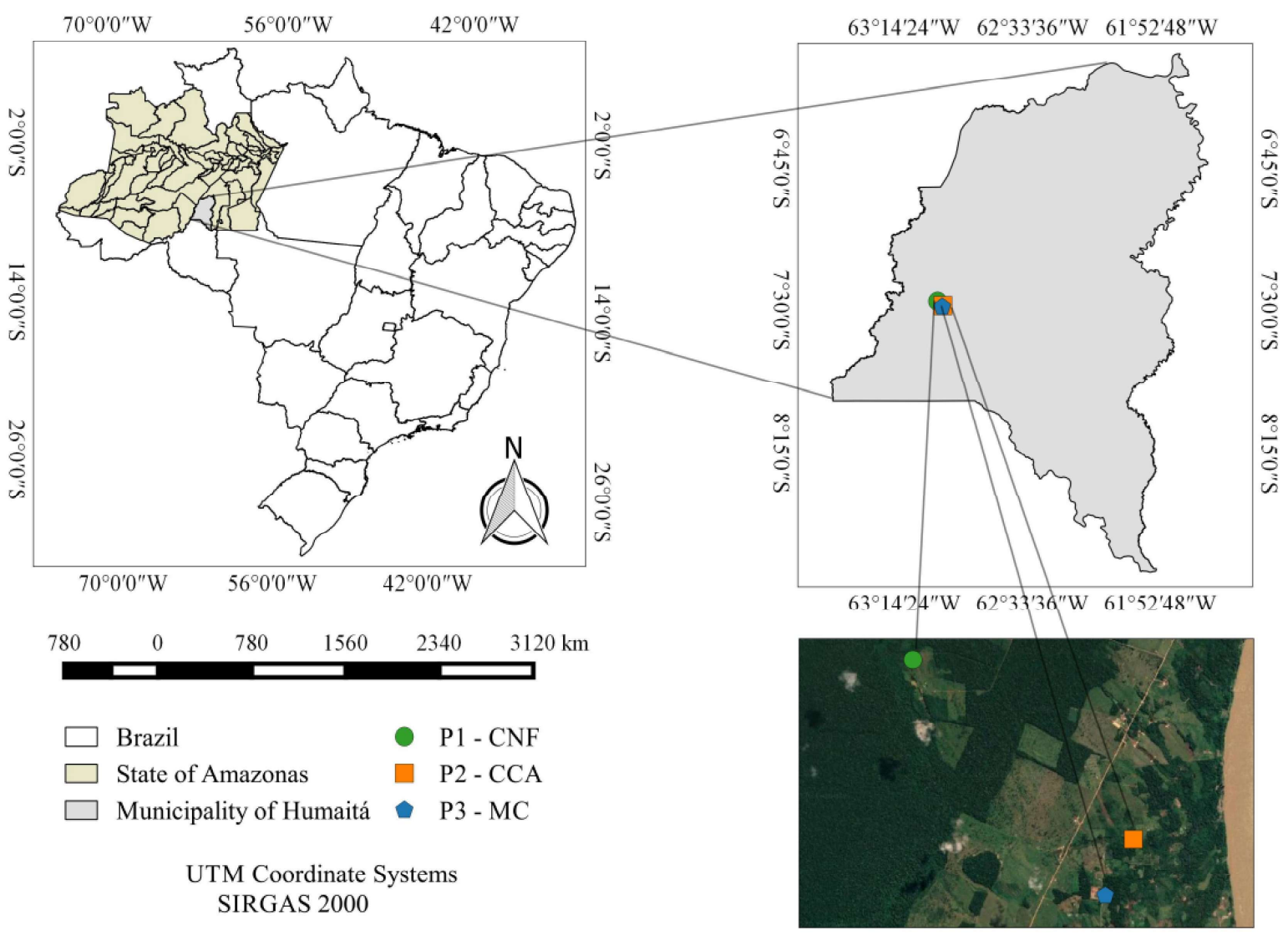

Figure 1 - Location of the three Conilon coffee plantation properties in the municipality of Humaitá, Amazonas studied during the period from July/2018 to June/2019. P1-CNF: coffee intercropped with native forest; P2-CCA: coffee combined with cupuaçu and açaí; P3-MC: coffee in monoculture.

Figura 1 - Localização das três propriedades de lavoura de café Conilon no município de Humaitá, Amazonas estudadas no periodo de julho /2018 a junho /2019. P1-CNF: café consorciado com floresta nativa; P2-CCA: café combinado com cupuaçu e açaí; P3-MC: café em monocultivo.

of Humaitá-AM, Brazil. The municipality is located on the left bank of the Madeira River, a tributary of the right branch of the Amazon River, about $200 \mathrm{~km}$ from Porto Velho and $675 \mathrm{~km}$ from Manaus by the BR-319 Highway (Figure 1).

In the rural area of the municipality, coffee plantations are located in the adjacent area of Alto Crato at the coordinates $07^{\circ} 26^{\prime} 52.14^{\prime \prime} \mathrm{S}$ and 6303'56.83" West (Property I, coffee plantation and native forest - CNF), $07^{\circ} 28^{\prime} 14.70^{\prime \prime} \mathrm{S}$ and $63^{\circ} 02^{\prime} 15.40^{\prime \prime}$ West (Property II, coffee plantation and a consortium of Amazonian fruit trees (Cupuaçu and Açaí) - CCA) and $07^{\circ} 28^{\prime} 40.62^{\prime}$ 'S and 63 $02^{\circ} 28.30^{\prime \prime}$ West (Property III, monoculture $-\mathrm{MC}$ ).

The climate in the region is typical for Amazonas, that is, a humid or sub-humid tropical climate with, according to Köppen, annual rainfall ranging from 2250 to $2750 \mathrm{~mm}$ and a short dry season. The annual average temperature varies from $24^{\circ} \mathrm{C}$ to $26^{\circ} \mathrm{C}$; the relative humidity of the air, which is quite high, varies from 85 to $90 \%$; and the average altitude is 90 meters above sea level.

\subsection{Collection and experimental design}

A sampling of adult insects was carried out monthly, on the last Saturday of every month, from July 2018 to June 2019. In order to capture the insects, impact traps made with two-liter polyethylene (PET) bottles were used, with a $12 \times 9 \mathrm{~cm}$ rectangular side opening. The bottles were painted red; a glass bottle $(20 \mathrm{ml})$ was fixed inside each one with a rubber cap perforated with a plastic straw that served as a diffuser

Revista Árvore 2021;45:e4524 
for the attractants. The attractant used was ethanol and methanol mixed at a 1:1 ratio. At each collecting, the traps were washed and more attractants were added to the diffusers for volume maintenance.

For each coffee crop, ten (10) traps were distributed, totaling thirty (30) traps used in this study. The traps were attached to the side of each coffee plant on wooden stakes that were $1.50 \mathrm{~m}$ high off the ground. The distribution of the traps was performed using an equidistant radius of $15 \mathrm{~m}$ from one to the next.

Paper filters were used to collect the insects from the traps. For each collection, the samples were properly separated by property, arranged in properly labelled folders and transported to the Plant Health laboratory of the Institute of Education, Agriculture and Environment of the Federal University of Amazonas (IEAA/UFAM) for screening and counting.

The phenophases of the coffee plant were based on the chronosequence of the second phenological year of C. canephora coffee, of the varieties 'Conilon' and 'Robusta' (Marcolan et al., 2009).

The meteorological information used was obtained from the automatic surface observation of the meteorological station in the municipality of Humaitá, Amazonas, from the National Meteorological Institute - INMET.

\subsection{Statistical analysis}

In this study, we consider H. hampei abundance to be the number of individuals collected. Point estimates and credible intervals of $H$. hampei abundance in each site or plant stage were obtained using a Bayesian model. Thus, in order to compute the posterior two chains with 10,000 samples, each was drawn using the NUTS algorithm. We used the first 5,000 samples to fine-tune the model. Model convergence was inspected visually and using R-hat. All analyses and plots were performed using Python 3.7 and the code were provided as a supplementary file (S1).

\section{RESULTS}

In general, the greatest population abundance of $H$. hampei in the three environments, CCA, $\mathrm{CNF}$ and $\mathrm{MC}$, occurs during the coffee flowering period, corresponding to the months of July through October/2018 (Figure 2). At the beginning of the grain formation period of the coffee fruits, starting in November/2018, a decrease in populations was also observed in the three coffee trees. The population increases again between April and May/2019, which includes the end of the fruit ripening period and the beginning of the rest period. Punctually, the largest population of the insect was observed in August/2018 in the $\mathrm{MC}$ and CCA crops, with a monthly average of 3,178 and 1,526, respectively. In the CNF crop, although there is a population peak in August as well, the highest value is registered in the month of October/2018, with average of 599 insects. The lowest population abundance of $H$. hampei occurs during the months of March and April, which is the period when the greatest number of ripe fruits are found on the plant. In this phenological stage of the plant, the average insect population in the MC, CCA and CNF crops was 4.0, 7.4 and 3.5 in March and 4.0, 3.4 and 5.5 in April, respectively.

The total insect population means in the three environments investigated were compared with climatic factors (Figure $3 \mathrm{~A}, 3 \mathrm{~B}$ and $3 \mathrm{C}$ ). The average temperature $\left({ }^{\circ} \mathrm{C}\right)$ and relative humidity of the air $(\mathrm{RH})$ did not vary much throughout the year (Figures $3 \mathrm{~B}$ and 3C); however, the rainfall increases sharply starting in November (the beginning of the fruit's grain formation

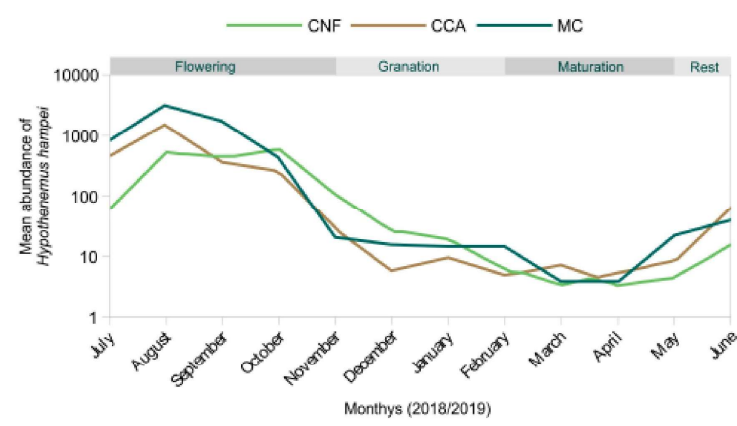

Figure 2 - Population dynamics of the coffee berry borer $(H$. hampei) in the three properties of Conilon coffee plantations: CNF - coffee intercropped with native forest; CCA - coffee intercropped with cupuaçu and açaí; $\mathrm{MC}$-coffee in monoculture.

Figura 2 -Dinâmica populacional da broca do café (H. hampei) nas três propriedades de café Conilon: CNF: café consorciado com floresta nativa; CCA: café combinado com cupuaçu e açaí; MC: café em monocultivo.

Revista Árvore 2021;45:e4524 

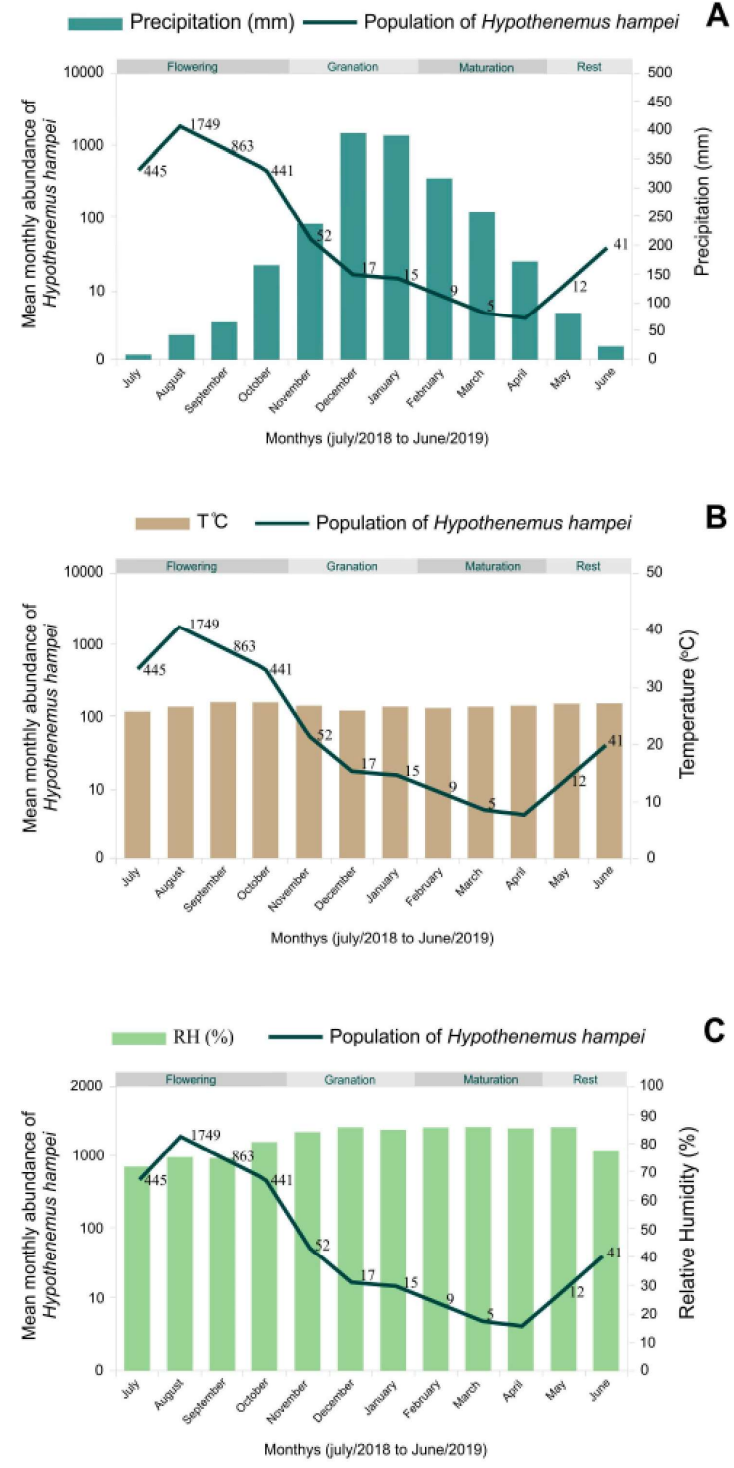

Figure 3 - Total population dynamics and climatic factors of the three coffee systems: $\mathrm{A}=$ Precipitation; $\mathrm{B}=$ Temperature and $\mathrm{C}=$ Relative humidity. The sample period corresponds to July/2018 through June/2019, in the municipality of Humaitá.

Figura 3 - Dinâmica populacional total e fatores climáticos dos três sistemas de café: $A=$ Precipitação; $B=$ Temperatura e $C=$ Umidade relativa. $A$ amostra do período corresponde a julho / 2018 a junho / 2019, no município de Humaitá.

period) (Figure 3A). The insect population diminishes sharply when rainfall increases, coinciding with the beginning of fruit grain formation. In the months of December/2018, January and February/2019, the highest rates of rainfall were recorded in the region, at 392,388 and $314 \mathrm{~mm}$ respectively.

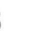

A
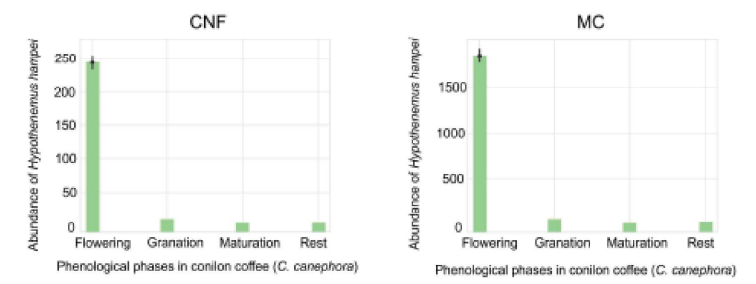

Figure 4 - Mean abundance of the coffee berry borer (H. hampei) from July/2018 to June/2019 at three Conilon coffee plantations: CNF - coffee intercropped with native forest; CCA - coffee intercropped with cupuaçu and açaí; $\mathrm{MC}$-coffee in monoculture. (A) Flowering months (July, August, September and October); (B) Months of grain expansion (November, December and January); (C) Months of Maturation (February, March and April); (D) Months of rest (May and June), in the municipality of Humaitá, Amazonas. Bayesian inference using the no-U-turn (NUTS) algorithm.

Figura 4 - Abundância média da broca do café (H. hampei) de julho / 2018 a junho / 2019 em três cafés Conilon plantios: CNF: café consorciado com floresta nativa; CCA: café combinado com cupuaçu e açai; $M C$ : café em monocultivo. ((A) Meses de floração (Julho, Agosto, Setembro e Outubro); (B) Meses de expansão dos grãos (Novembro, Dezembro e Janeiro): (C) Meses de Maturação (Fevereiro, Março e Abril); (D) Meses de repouso (Maio e Junho), no município de Humaitá, Amazonas. Inferência bayesiana usando o algoritmo no-U-turn (NUTS).

In general, the lowest averages of total insect population were found in March and April/2019, at 5 and 4, respectively (Figure 3A, 3B and 3C). On the other hand, in the dry period, in the months of July, August and September/2018, the highest total average number of insects is observed, at 445, 1749 and 863, respectively. The rainfall index in those same months (July to September/2018) were 6.4, 39.8 and 62.4 $\mathrm{mm}$, respectively (Figure $3 \mathrm{~A}$ ); it can be noted that the defined dry and rainy periods are evident.

On the other hand, the lowest total population averages in the three environments are recorded at the end of the rainy season, which includes the months of March and April. During this period of the year, the total average population in the three coffee planting systems evaluated is only 5 specimens in the month of March and 4 specimens in April (Figure 3A).

Revista Árvore 2021;45:e4524 

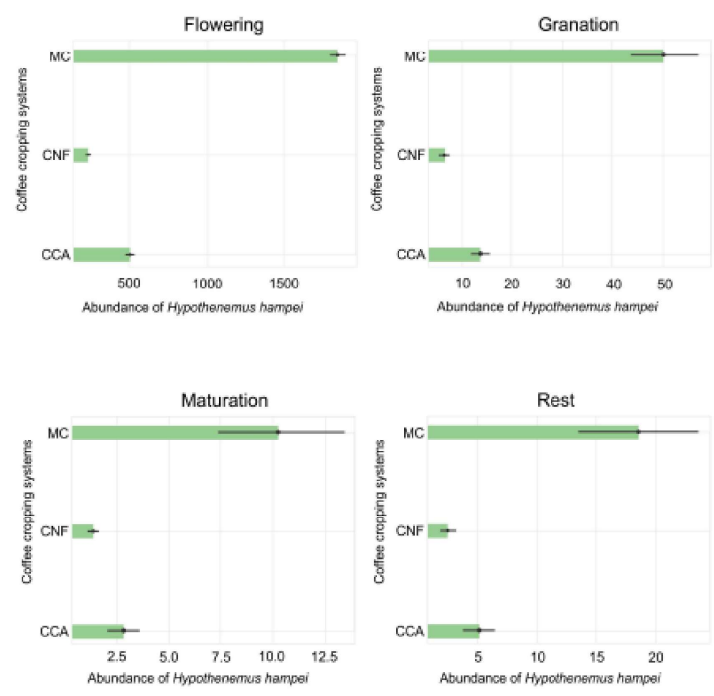

Figure 5 - Abundance of the coffee berry borer (H. hampei) from July/2018 to June/2019 in the four different phenological stages of coffee: (A) Flowering months (July, August, September and October); (B) Months of grain expansion (November, December and January); (C) Months of Maturation (February, March and April); (D) Months of rest (May and June), in the municipality of Humaitá, Amazonas. CNF - coffee intercropped with native forest; CCA - coffee intercropped with cupuaçu and açaí; MC -coffee in monoculture. Bayesian inference using the no-U-turn (NUTS) algorithm.

Figura 5 - Abundância da broca do café (H. hampei) no periodo de Julho / 2018 a junho / 2019 nos quatro diferentes fenológicos estágios do café: (A) Meses de floração (Julho, Agosto, Setembro e Outubro); (B) Meses de expansão dos grãos (Novembro, Dezembro e Janeiro); (C) Meses de Maturação (Fevereiro, Março e Abril); (D) Meses de repouso (Maio e Junho), no município de Humaitá, Amazonas. CNF: café consorciado com floresta nativa; CCA: café combinado com cupuaçu e açaí; MC: café em monocultivo. Inferência bayesiana o algoritmo no-U-turn (NUTS).

The average temperature oscillation between July/2018 and June/2019 was from $25.6{ }^{\circ} \mathrm{C}$ to 27.1 ${ }^{\circ} \mathrm{C}$ considering each month respectively, while the average humidity levels were between $71 \%$ and $79 \%$ during the flowering period of the plant. The highest relative humidity averages are observed between February and April/2018, varying between 84.2 and $84.4 \%$, which corresponds to the plant's phenological phases of the beginning of fruit maturation and the beginning of the rest period (Figures $3 \mathrm{~B}$ and $3 \mathrm{C}$ ).

According to the analyzes, the mean abundance of $H$. hampei varies among the plant stages no matter the type of system. The highest mean abundance occurs during the flowering stage when the mean abundance reaches 1853.6 (Credible interval: 1806,04 - 1903.1) individuals in MC; 503.66 (Credible interval: $481.84-$ 525.57) in CCA and 241.91 (Credible interval: 227.18 - 257.076) in CNF (Figure 4). With this, it was noted that at the time of flowering, there was a significant difference in the abundance of $H$. hampei in the coffee monoculture (MC) compared to the other crops.

The abundance of the insect was also compared between the different phenological stages of the plant for each coffee crop investigated. The data revealed that there are significant differences in insect populations in MC, CCA and CNF. No matter the phenological stage of the plant, $\mathrm{MC}$ had the highest mean abundance of $H$. hampei (Mean: 508.84; Cr: 508.84 - 542.50), followed by CCA (Mean: 172.82; Cr: 164.63 - 181.04) and CNF (83.00; Cr: 77.65 88.51) (Figure 5).

\section{DISCUSSION}

The population dynamics of H. hampei are directly related to the phenological stages of coffee. In general, the flowering period of coffee is the main factor that influences an increase in the population abundance of this species in the crop. This observation in Amazonas is in line with another study that confirms greater flight activity of this insect during the flowering period of the plant (Fernandes et al., 2015). Although details about semiochemicals from coffee flowers that attract $H$. hampei are still unknown, the behavior of $H$. hampei is altered during the period of coffee flowering. In this context, studies on attractive substances are important for the agroecological management of this pest in coffee plantations (Castro et al., 2017). Investigations into the interaction of this insect with its host plant are noteworthy, along with the emphasis that is given to the search for plant semiochemicals that are attractive to this pest (Jaramillo et al., 2013; Mendesil et al., 2009). In summary, the greater flight activity of $H$. hampei during the coffee flowering period makes clear the importance of investigating the volatile attractants emanating from its flowers, especially because the changes in the insect's behavior are also related to its reproduction and define the population structure in the environment.

In the months of maturation of coffee fruits (March and April/2018), low insect abundance is observed, probably because the baited traps capture

Revista Árvore 2021;45:e4524 
only adult colonizing females in flight activity. At that time, the fruits are suitable for the construction of galleries and oviposition (Mathieu et al., 1997). Thus, a large part of the H. hampei population is still in their immature form (egg, larva or pupa) within the fruits.

In relation to climatic factors, it was observed that the highest population density of $H$. hampei occurs during the months of low rainfall. The average temperature and relative humidity values do not have sudden variations throughout the year nor do they seem to exert much influence on the population dynamics of the insect in the Amazonian environment. A reduction in the $H$. hampei population was observed starting in the month of November when rainfall increases sharply. Thus, rainfall was the most relevant climatic factor in reducing the insect population in Amazonas. This observation is corroborated by other studies that demonstrate the interference of rainfall levels in the population development of this species (Ferreira et al., 2000; Laurentino and Costa, 2004; Oliveira et al., 2017; Souza and Reis, 1997). Therefore, rain can influence the intensity of pest infestation, decreasing the rate of infestation in years with precipitation during the periods of grain formation and fruit maturation (Laurentino and Costa, 2004). Besides that, the sharp reduction in the population at the beginning of the rainy season must also imply that there are physiological changes that occur with $H$. hampei that makes it enter the diapause phase during the fruit granulation period (off-season), thus reducing the population at this time (López-Guillén et al., 2011; Damon, 2000).

It was observed that in the coffee plantation implanted within the native forest (CNF) and in the coffee plantation intercropped with cupuaçu and açaí (CCA), there is a lower abundance of the insect in the coffee flowering months and in the other phenological stages of coffee when compared to the monoculture coffee crop (MC), being significantly higher in the monoculture system. Some studies have shown that environmental factors such as wind turbulence caused by the plant community in a given environment can affect the transport of volatile attractants to the receiving insects (Aartsma et al., 2017). Thus, the data suggest that the agroforestry system may influence the shape of the spatial dispersion of the odor of attractants to $H$. hampei from coffee flowers, affecting the flight activity of colonizing females, and consequently, the population size of the insect. Besides that, it is known that agroforestry systems favor ecosystem services. For example, this system offers a greater diversity of natural enemies in the community which serve the purpose of biological pest control (Harterreiten-Souza et al., 2014).

In all the phenological phases of coffee, among the three coffee plantations, the population abundance of H. hampei is significantly lower in the CNF crop compared to the other two. It is noteworthy that the CNF crop (coffee intercropped with native forest), is inserted in an environment with greater biodiversity in relation to the other two coffee plantations, MC and CCA. Thus, due to the greater biodiversity of the environment, the presence of natural enemies favors low maintenance of the $H$. hampei population when compared to the other two coffee planting systems. Studies show that the biodiversity of the environment enhances the action of several species of natural enemies that favor the suppression of the insect pest population. The diversity of natural enemies in the environment provides a greater food niche for this class of organism, resulting in a diversified maximization of attacks such as places, moments and different stages of life of the insect pest (Snyder, 2019). This fact explains the significant difference in the $H$. hampei population between the three coffee cultivation systems, with a greater abundance of the pest in the monoculture system (MC) and the plantation system with native forest (CNF) showing less abundance of the pest.

As previously mentioned, never before has any type of study been done on $H$. hampei population dynamics and behavior in coffee crops in this region of Brazil. This fact converges with strategic ideas that can be used as alternative ways of managing the species in this Brazilian Amazonian region.

\section{CONCLUSION}

The largest population peaks of $H$. hampei in coffee plantations in the Amazon environment are recorded in the coffee flowering period and during the dry period of the year. The greater population abundance of the insect in monoculture (MC) demonstrates that this type of system favors the pest population. The high rainfall in the environment resulted in low population density of the coffee berry borer. Studies on the bioecology of $H$. hampei in different types of planting systems are important for

Revista Árvore 2021;45:e4524 
future implementations of integrated management programs for this important pest considering the peculiarities of the Amazonian environment.

\section{AUTHOR CONTRIBUTIONS}

J.F.B manuscript preparation, execution of the project and organizing data. R.S.Q technical assistance and contributed to the writing. M.S.S. and M.R.A conception and design of the study, analysis and interpretation of data, drafting and critically revising the manuscript.

\section{ACKNOWLEDGMENTS}

We are most grateful for the helpful suggestions and guidances of Ph.D. Moreno Magalhães de Souza Rodrigues (FIOCRUZ - Oswaldo Cruz Foundation), in the statistic analyses. We thank LIOP (Laboratory of Ichthyology and Fisheries Management of the Madeira River Valley)/IEAA and Fitossanity Laboratory of the IEAA/UFAM for support of this research. Finally, the authors acknowledge the financial support given by CAPES (Coordenação de Aperfeiçoamento de pessoal de Nível Superior), CNPq (Conselho Nacional de Desenvolvimento Científico e Tecnológico) and UFAM (Universidade Federal do Amazonas).

\section{REFERENCES}

Aartsma Y, Bianchi FJJA, Werf van der W, Poelman EH, Dicke M. Herbivore-induced plant volatiles and tritrophic interactions across spatial scales. New Phytologist. 2017;216(4):1054-1063. doi: 10.1111/ nph. 14475.

Castro AM, Tapias J, Ortiz A, Benavides P, Góngora CE. Identification of attractant and repellent plants to coffee berry borer, Hypothenemus hampei. Entomologia Experimentalis et Applicata. 2017;164(2):120-130. doi: 10.1111/eea.12604.

Costa JNM, Teixeira CAD, Ribeiro PA, Silva RB, Silva DA. Flutuação de infestação da broca-do-café (Hypothenemus hampei, Ferrari) em Rondônia. Porto Velho: Embrapa CPAF-Rondônia; 2002 [Cited 2020 april 26]. Available in: http://www.sbicafe.ufv. $\mathrm{br} / \mathrm{bitstream} /$ handle/123456789/9151/Boletim\%20 de\%20Pesquisa\%20e\%20Desenvolvimento_11. pdf? sequence $=1 \&$ is Allowed $=y$.

Damon AA. Review of the biology and control of the coffee berry borer, Hypothenemus hampei (Coleoptera: Scolytidae). Bulletin Entomological Research, 2000; 90 (6): 453-465. doi: 10.1017/ S0007485300000584.

Fernandes FL, Picanço MC, Fernandes MS, Dângelo RAC, Souza FF, Guedes RNC. A new and highly effective sampling plan using attractant-baited traps for the coffee berry borer (Hypothenemus hampei). Journal of Pest Science. 2015;88(2):289-299. doi: 10.1007/s10340-014-0622-2.

Ferreira AJ, Bueno VH, Moraes JC, Carvalho GA, Buenos Filho JSDS. Dinâmica populacional da broca-do-café Hypothenemus hampei (Coleoptera: Scolytidae) em Lavras, MG. Anais da Sociedade Entomológica do Brasil. 2000;29(2):237-244. doi: 10.1590/S0301-80592000000200005.

Figueiredo VG, Carrero GC, Cenamo MC, Machado AM. Café em agrofloresta para o fortalecimento da economia de baixo carbono em Apuí, AmazonasBrasil. Cadernos de Agroecologia. 2016;10 (3).

Gherlenda NA, Moore BD, Haigh AM, Johnson SN, Riegler M. Insect herbivory in a mature Eucalyptus woodland canopy depends on leaf phenology but not CO2 enrichment. BMC Ecology, 2016;16 (47). doi: 10.4225/35/57e49ec6dd3eb.

Harterreiten-Souza ES, Togni PHB, Pires CSS, Sujii ER.. The role of integrating agroforestry and vegetable planting in structuring communities of herbivorous insects and their natural enemies in the Neotropical region. Agroforest Systems. 2014; 88(2):205-219. doi:10.1007/s10457-013-9666-1.

Homma AKO. História da agricultura na Amazônia: da era pré-colombiana ao terceiro milênio. Brasília: Embrapa Informação Tecnológica, 2003. ISBN 857383-170-7.

Jaramillo J, Torto B, Mwenda D, Troeger A, Borgemeister C, Poehling HM, Francke W. Coffee berry borer joins bark beetles in coffee klatch. PloS one. 2013;8(9). doi: 10.1371 / journal. pone. 0074277 .

Kapkoti B, Rawal RS, Joshi RK. Insect Pollinators of Brassica campestris in Kumaun, West Himalaya: Influence of Crop Composition, Altitude and Flowering Phenology. National Academy Science Letters. 2016; 39(5):389-394. doi: 10.1007/s40009016-0500-y.

Revista Árvore 2021;45:e4524 
Laurentino E, Costa JNM. Descrição e caracterização biológica da broca-do-café (Hypothenemus hampei, Ferrari 1867) no Estado de Rondônia. Porto Velho: Embrapa Rondônia, 2004.

López-Guillén G, Carrasco JV, Cruz-López L, Barrera JF, Malo EA, Rojas JC. Morphology and structural changes in flight muscles of Hypothenemus hampei (Coleoptera: Curculionidae) females. Environmental entomology. 2011;40(2):441-448. doi:10.1603 /EN10181.

Marcolan AL, Espindula MC. Café na Amazônia. Brasília, DF: Embrapa Rondônia, 2015. ISBN 97885-7035-469-3.

Marcolan AL, Ramalho AR, Mendes AM, Teixeira CAD, Fernandes CF, Costa JNM, Vieira Júnior JR, Oliveira SJM, Fernandes SR, Veneziano W. Cultivo dos Cafeeiros Conilon e Robusta para Rondônia. 3. ed. rev. atual. DF: Embrapa Rondônia, Emater-RO. 2009 .

Masante-Roca I, Anton S, Delbac L, Dufour MC, Gadenne C. Attraction of the grapevine moth to host and non-host plant parts in the wind tunnel: effects of plant phenology, sex, and mating status. Entomologia Experimentalis et Applicata. 2007;122(3): 239-245. doi: $10.1111 /$ j.1570-7458.2006.00510.x.

Mathieu F, Brun JO, Frérot B. Factors related to native host abandonment by the coffee berry borer Hypothenemus hampei (Ferr.) (Col., Scolytidae). Journal of Applied Entomology. 1997; (121). doi: 10.1111/j.1439-0418.1997.tb01389.x.

Mendesil E, Bruce TJ, Woodcock CM, Caulfield JC, Seyoum E, Pickett JA. Semiochemicals used in host location by the coffee berry borer, Hypothenemus hampei. Journal of chemical ecology. 2009; 35 (8): 944-950. doi: 10.1007/s10886-009-9685-6.

Nielsen AL, Hamilton GC, Shearer PW. Seasonal Phenology and Monitoring of the Non-Native Halyomorpha halys (Hemiptera: Pentatomidae) in Soybean. Environmental Entomology. 2011; 40(2):231-238. doi: 10.1603/EN10187.

Oliveira BS, Herzog TT, Silva MBD, Gontijo I, Partelli FL. Distribuição espacial do ataque da broca-do-café no café conilon. Coffee Science, 2017; 12(4):526-533. doi:10.25186/cs.v12i4.1360.
Posledovich D, Toftegaard T, Wiklund C, Ehrlén J, Gotthard K. Phenological synchrony between a butterfly and its host plants: Experimental test of effects of spring temperature. Journal of Animal Ecology. 2018;87(1):150-161. doi: 10.1111/13652656.12770.

Price PW. Insec Ecology. $3^{\text {a }}$.ed. New York:John Wiley \& Sons; 1997. ISBN: 978-0521542609.

Snyder WE. Give predators a complement: conserving natural enemy biodiversity to improve biocontrol. Biol Control. 2019;(135). doi: 10.1016/j. biocontrol.2019.04.017.

Souza JC, Reis P, Silva R, Toledo MD. Cafeicultor: saiba como monitorar e controlar a broca-do-café com eficiência. Lavras: Epamig (Circular Técnica, 291); 2018

Souza JC, Reis PR. Broca-do-café: histórico, reconhecimento, biologia, prejuízos, monitoramento e controle. $2^{\mathrm{a}}$. ed. Belo Horizonte: Epamig (Boletim técnico 11:50); 1997.

Souza MS, Costa JNM, Espindula MC, Silva AA. Performance of baited traps for integrated management of Hypothenemus hampei Ferrari (Coleoptera: Scolytinae) in a conilon coffee crop in Rondônia State, Brazil. EntomoBrasilis. 2020; 13. doi: 10.12741/ebrasilis.v13.e913.

Souza MS, Costa JNM, Espindula MC, Silva AA. Response of Hypothenemus hampei (Coleoptera: Curculionidae) to semiochemicals and blends using baited traps in coffee fields. Australian Jounal of Crop Science, 2018;12(6):961-966. doi: 10.21475/ ajcs.18.12.06.PNE1057.

Souza MS, Almeida A, Teixeira CAD, Costa JNM. Parasitismo na população da broca-do-café Hypothenemus hampei (Ferrari) (Coleoptera: Scolytidae), pelo parasitoide Cephalonomia stephanoderis Betrem (Hymenoptera: Bethylidae). EntomoBrasilis, 2014;7(3):178-182. doi: 10.12741/ ebrasilis.v7i3.402.

Yadav R, Chang NT. Effects of temperature on the development and population growth of the melon thrips, thrips palmi, on eggplant, Solanum melongena. Journal of Insect Science. 2014;14(1). doi: $10.1093 / \mathrm{jis} / 14.1 .78$.

\section{Revista Árvore 2021;45:e4524}

